\title{
Pés e cansaços: imagens e memórias na obra Descanso, de Hugo
}

\section{Mund Jr.}

Feet and fatigue: images and memories in the work descanso, of Hugo Mund Jr. Clarissa Santos Silva

Mestra em Artes Visuais pela Universidade do Estado de Santa Catarina (UDESC). Professora da Universidade Federal do Sul da Bahia (CSC/Porto Seguro) - clarissa.santos@ufsb.edu.br

\section{Resumo}

Neste artigo, abarcam-se questões relativas a algumas das recentes constituições para abordagem da História da Arte, enfocando os conceitos de imagem, montagem, imaginação e memória, através das bases fornecidas por teóricos como Benjamin, Warburg, DidiHubermann, dentre outros, que os estudam e corroboram. Tendo por base tais perspectivas, aproximamo-nos de uma construção de leitura simbólica e memorial da obra Descanso (1955), de Hugo Mund Jr.

Palavras-chave: História da Arte. Imagem. Memória. Hugo Mund Jr.

\section{Abstract}

This paper addresses issues related to some of the recent constitutions to approach the History of Art, focusing on the concepts of image, assembly, imagination and memory, through the bases provided by theorists as Walter Benjamin, Aby Warburg, Didi-Hubermann, among others that study and corroborate them. Based on such perspectives, we approach a construction of symbolic and memorial Reading of the work Descanso (1955), of the brazilian artist Hugo Mund Jr.

Keywords: History of Art. Image. Memory. Hugo Mund Jr.

"[...] na caixa das coisas vivas, coloquei as imagens" (Etienne Samain ${ }^{1}$ ).

Recebido em: 23/04/2017

Aceito em: 13/06/2018

\footnotetext{
${ }^{1}$ SAMAIN, Etienne. Antropologia, imagens e arte: um percurso reflexivo a partir de Georges Didi-Huberman. Cadernos de Arte e Antropologia, [s. I.], v. 3, n. 2, p.47-55, jan. 2014. Disponível em:

<https://journals.openedition.org/cadernosaa/391?file=1>. Acesso em: 12 jul. 2018.
} 
Aproximar-se das constituições da arte na atualidade requer achegar-se ao território do pensamento complexo, multifacetado, de múltiplas temporalidades em diálogo. As perspectivas teóricas do campo da História da Arte, com seus regimes de verdade ${ }^{2}$, têm caminhado pari passu a estas noções, fervilhantes desde o pós-Primeira Guerra, nos mais diversos campos de saber das ciências humanas e sociais. Assim, temos que:

Na atualidade, a consciência da complexidade do conhecimento não permite mais o historiador isolar e purificar a arte, ao procurar dar unidade aos fenômenos e se limitar apenas a euchronia. Ora o objeto da História da Arte não é a unidade do período descrito, mas sua dinâmica, o que supõe movimentos em todos os sentidos, tensões e contradições (KERN, 2009, p. 97).

É preciso aclarar, primordialmente, que o objeto fundamental da pesquisa em História da Arte é a imagem: a realização visual, estética; a imagem com seus contornos próprios, seus pensamentos intrínsecos e perfil incendiário (DIDI-HUBERMANN, 2012; SAMAIN, 2014). Fundamenta-se, assim, uma aproximação ardente: acendem-se as percepções iconográficas, incendeia-se o tempo cronológico, o pensamento linear, a montagem histórica; e ficam as memórias em brasa, como montagens anacrônicas no tecido chamuscado do olhar.

Há na imagem essas forças invisíveis, potências e sobrevivências (conceitos trabalhados por Didi-Hubermann e Aby Warburg, respectivamente) que efetivam mais do que um registro histórico, cronológico, pois resguardam a capacidade de reativar memórias, colocá-las à mesa, revisitá-las e remontá-las, como se o passado (mesmo imortalizado na imagem) nunca cessasse de reconfigurar-se. Disse Walter Benjamin: “Não é que o passado lance a sua luz sobre o presente ou o presente sobre o passado. Uma imagem, pelo contrário, é aquilo em que o Outrora encontra o Agora para formar uma constelação" (BENJAMIN apud CANTINHO, 2016, p. 10).

Na poética de Marcel Proust, podemos vislumbrar as referidas potências e sobrevivências das imagens da memória que autor constrói, diante de nós, esse entrecruzamento de tempos, espaços, reminiscências e representações, em todo seu anacronismo e tempestividade. Em "No caminho de Swann", o volume I dos sete que compõem a obra "Em busca do tempo perdido", encontramos a descrição fantástica da experiência do sujeito no umbral entre vigília e sono,

\footnotetext{
${ }^{2}$ A concepção sobre os "regimes de verdade" foi abordada na disciplina Teorias da História da Arte, do PPGAV-UDESC, ministrada pela Profa. Dra. Sandra Makowiecky. Este artigo é fruto das abordagens e reflexões suscitadas neste componente curricular.
} 
transpassando realidade e lembrança, passado e presente; ou entre "visível e invisível" como na acepção de Merleau-Ponty (2003). Disse Proust (2006, p. 19-20):

A imobilidade das coisas que nos cercam talvez lhes seja imposta por nossa certeza de que essas coisas são elas mesmas e não outras, pela imobilidade de nosso pensamento perante elas. A verdade é que, quando eu assim despertava, com o espírito a debater-se para averiguar, sem sucesso, onde poderia achar-me, tudo girava em redor de mim no escuro, as coisas, os países, os anos. Meu corpo, muito entorpecido para se mover, procurava, segundo a forma de seu cansaço, determinar a posição dos membros para daí induzir a direção da parede, o lugar dos móveis, para reconstruir e dar um nome à moradia onde se achava. Sua memória, a memória de suas costelas, de seus joelhos, de suas espáduas, apresentava-lhe, sucessivamente, vários dos quartos onde havia dormido, enquanto em torno dele as paredes invisíveis, mudando de lugar segundo a forma da peça imaginada, redemoinhavam nas trevas. $E$ antes mesmo que meu pensamento, hesitante no limiar dos tempos e das formas, tivesse identificado a habitação, reunindo as diversas circunstâncias, ele - meu corpo - ia recordando, para cada quarto, a espécie do leito, a localização das portas, o lado para que davam as janelas, a existência de um corredor, e isso com os pensamentos que eu ali tivera ao adormecer e que reencontrava ao despertar. Meu corpo anquilosado, procurando adivinhar sua orientação, imaginava-se, por exemplo, virado para a parede, em um grande leito de dossel, e eu logo dizia comigo: "Pois não é que acabei adormecendo antes que mamãe me viesse dar boa-noite!"; achava-me então no campo, em casa de meu avô, morto havia muitos anos; e meu corpo, o flanco sobre o qual eu repousava, fiel zelador de um passado que meu espírito nunca deveria esquecer, recordava-me a chama da lâmpada de cristal da Boêmia, em forma de urna suspensa do teto por leves correntes, a lareira de mármore de Viena, em meu quarto de dormir, em Combray, em casa de meus avós, em remotos dias que naquele instante eu julgava atuais, sem formar deles uma imagem exata e que tornaria a ver muito melhor dali a momentos, quando despertasse de todo. [...] Essas evocações torvelinhantes e confusas nunca duravam mais que alguns segundos; muitas vezes, minha breve incerteza do local em que me achava não permitia tampouco distinguir umas das outras as diversas suposições que a constituíam, da mesma forma que não isolamos, ao ver um cavalo correndo, as posições sucessivas que nos mostra o cinetoscópio.

Essa expansão incendiária das lembranças e visões que compõem a hipnagogia da personagem de Proust, nos permite elucubrar que as imagens são como pequenas porções de gelo e fogo: congelam cenários, momentos, visões, mas não cessam de incendiar as percepções, o tempo, o olhar. Nelas solidificam-se povos, suas culturas, gestos e imaginários, ao mesmo tempo em que ardem as memórias anacrônicas, as histórias atemporais, as concepções sociais resistentes.

As grandes questões humanas sobrevivem nas imagens, é através delas que se conhecem outras culturas, outros povos, e é na imagem, imagem como noção operatória e não como mero suporte iconográfico, que aparecem as sobrevivências, anacrônicas, atemporais, memórias enterradas e que ressurgem (MAKOWIECKY, 2013, p. 6). 
A história construída a partir desse tipo de aproximação com as imagens, portanto, não associa-se à temporalidade cronológica; não interpela o reino de Chronos, mas talvez o de Kairós, pois relaciona-se com a intensidade, o momento oportuno, o recorte eternizado, em sua potência de ser qualitativamente revisitado. Neste sentido, "o tempo não significa necessariamente o passado, mas a memória, porque ela decanta o passado e humaniza, configurando-o. A memória é psíquica no seu processo e anacrônica nos seus efeitos de montagem ao conectar o inconsciente" (KERN, 2009, p. 97). É Michel de Certeau que, ao tratar da escrita da história, explicita que:

\begin{abstract}
A história está, pois, em jogo nessas fronteiras que articulam uma sociedade com o seu passado e o ato de distinguir-se dele; nessas linhas que traçam a imagem de uma atualidade, demarcando-a de seu outro, mas que atenua ou modifica, continuamente, o retorno do "passado". Como na pintura de Miró, o traço que desenha diferenças através de contornos e que torna possivel uma escrita (um discurso e uma "historicização") é atravessado por um movimento que the é contrário. Ele é vibração de limites. A relação que organiza a história é uma relação mutável, na qual nenhum dos (dois) termos é o referente estável (CERTEAU, 1982, p. 48).
\end{abstract}

A imagem como fruto desses tempos impuros, pensamento complexo e ordenação constelar, requer essa abordagem a partir da memória. "Por isso, o historiador é o que tem a capacidade de ler as imagens ou [...] "ler o que nunca foi escrito" e que se deixa vislumbrar pela rememoração e pela possibilidade de "reactivação" do potencial das imagens" (CANTINHO, 2016, p. 10). A memória, por sua vez, parece demandar um tipo de aproximação específica (que se tornará fundamental na constituição historiográfica recente): a montagem.

A construção de um conhecimento por montagem (de textos, tempos, imagens, citações, entre outros) possibilita aclarar as impurezas, anacronismos, contradições e sobrevivências presentes na constituição da nossa historicidade. Sobremaneira, no contexto da História da Arte, permite entrever a potencialidade dialética das imagens, seus percursos e leituras desencadeados da linearidade e progressão do continuum temporal (habitualmente relacionado ao que é histórico, cronológico).

O pensamento diante da imagem, nesse sentido, opera através da montagem, na religação de pontos aparentemente desmembrados, efetivando através da rememoração (em toda sua complexidade) uma orquestração realizada de maneira constelar. Nesta constelação, também 
as estrelas vêm de tempos distintos, díspares, distantes, mas convergem em seus asterismos; fulguram e cintilam sob o mesmo céu.

[...] a imagem comporta em si a memória de um acontecimento forte, que reenvia para experiências originárias, como uma espécie de marca ou um traço sobre os estratos mais arcaicos da consciência. É precisamente por essa razão que a imagem traz consigo uma carga energética, destruindo, a partir desse potencial a ideia de um modelo de história como narrativa, linear e contínua. Isto é, em lugar de um encadeamento causal de acontecimentos, numa lógica de continuidade linear, há "saltos", os instantes dialéticos que recompõem a ideia de história como "imaginal" ou figurativa, correspondendo a uma ideia de constelação (CANTINHO, 2016, p. 12).

É válido salientar, no entanto, que não há como pensar na ideia de uma história como "imaginal" desvinculada do exercício primordial, sem o qual não há imagem: a imaginação. Disse Didi-Hubermann que "é um enorme equívoco querer fazer da imaginação uma pura e simples faculdade de desrealização" (DIDI-HUBERMANN, 2012, p. 208). Pelo contrário, diante da imagem, a imaginação é o que permite realizar: leituras, construções, historicidade. Possibilita perceber os sinais, emblemas e sobrevivências postos, prenhes de seus significados e ressemantizações.

A imaginação é processo fundamental na religação entre os tempos, imagens e histórias, diante de uma imagem. Possibilita ir além do dado, do posto, do figurado nas linhas e cores; avança pela sensação, articula todo e partes, presentes, futuros e pretéritos, relaciona partes e recortes; moldura e detalhes. E é no detalhe, partícula residual da construção figurativa, pequeno tracejo do que deseja ser contado, que, por vezes, está a célula dialética, o rompimento temporal, a potencialidade discursiva e o caráter mnemônico e engramático ${ }^{3}$ da imagem.

Cada acontecimento agindo sobre a matéria viva deixa aí um vestígio, que Semon chama engrama. A energia potencial conservada neste engrama pode ser reactivada e descarregada em certas condições. Pode-se dizer que o organismo age duma certa maneira porque ele se lembra do acontecimento precedente (GOMBRICH apud AGAMBEN, 2009, p.136).

Na obra de Warburg (2015), reconheceremos o engrama como uma espécie de memória social e coletiva, capaz de ser reativada pela potência de estímulos similares ao originário, como no

\footnotetext{
${ }^{3}$ As noções de mnemosyne e engrama, assim como de sobrevivência (nachleben) e pathosformel, podem ser melhor compreendidos através dos estudos e métodos propostos por Aby Warburg (1866-1929). Seus principais trabalhos podem ser encontrados no livro "Histórias de fantasma para gente grande" (São Paulo: Companhia das Letras, 2015).
} 
caso das imagens através dos seus símbolos, emblemas, fórmulas. O detalhe é engramático, e o engrama enquanto este registro de memória - vestígio impresso como que por instinto na psique humana -, é um dos meios pelos quais nos é permitido constelar referências atemporais e orquestrar conhecimentos através da montagem.

Falar em engrama, na concepção warburguiana, é recordar que este teórico aproximavase dos estudos da arte e da história para constituição de uma espécie de ciência da cultura; para busca de uma historicidade anacrônica e dinâmica, capaz de articular estas relações de tempos, símbolos, gestos e sobrevivências, na cultura humana. A memória, em Warburg, portanto, é antes de tudo a memória social, coletiva; construto do humano e por isso impura, não-linear, complexa.

\section{Dos pés cansados: construções a partir da obra Descanso, de Hugo Mund Jr.}

Os pressupostos e perspectivas que nortearam estas construções teóricas e metodológicas do pós-Guerra, evidenciadas nos trabalhos de teóricos como Benjamin, Warburg, Arendt, entre outros no campo das investigações das ciências sociais e humanas, reverberaram em múltiplos contextos, concepções e propostas. Ressalta-se a visão do homem enquanto ser social, construtor de pensamento e cultura; ser de relações, memórias e histórias.

Na História da Arte, a concepção da existência de um imaginário social, "memória social e coletiva" (engrama), vai permear sobremaneira as ideias e produções modernistas. A Arte Moderna, em suas representações e semântica, intenciona dar visibilidade aos sujeitos cotidianos, seus costumes, maneiras, gestos; recobrar os aspectos de sua cultura, especialmente naquilo que ela tem de coletivo.

No estado de Santa Catarina, o Círculo de Arte Moderna (CAM) encabeçou as movimentações e publicações que semeariam a estética modernista, principalmente na capital do estado, através da Revista Sul (1944-1957)4. A afirmação e efervescência desses artistas, porém, vai acontecer através do Grupo de Artistas Plásticos de Florianópolis (GAPF), que emergiu no final da década de 50 na cidade. Este "grupo de artistas torna "coisa", torna não mortal, não perecível, aquela história vivida por pessoas que vão compor um imaginário social" (LEHMKUHL, 1996, p. 14) e enleva a produção catarinense através de publicações, eventos, exposições, entre outros.

\footnotetext{
${ }^{4}$ Lehmkuhl, 1996.
} 
Procuram dar publicidade a toda sorte de vivências, atitudes e ações que só eram tratadas na esfera do privado e que adquirem valor cultural e político. Temas do cotidiano ganham status de obra de arte ao serem estetizados e politizados nas palavras dos escritores e no pincel do artista. Um mundo vai sendo tocado e transformado em "coisa", pela mão do artista que lhe confere imortalidade (Ibidem, p.39).

Entre os artistas que compunham estas movimentações pela renovação modernista na arte catarinense está o poeta e artista plástico Hugo Mund Jr. Com uma produção articulada entre literatura e gravuras, o artista revela a produção de figurações a partir do imaginário social da cidade, seus sujeitos e personagens; seu espaço e memória.

Figura 1 - Descanso, Hugo Mund Jr. 1955. Xilogravura sobre papel, 21 x $24 \mathrm{~cm}$.

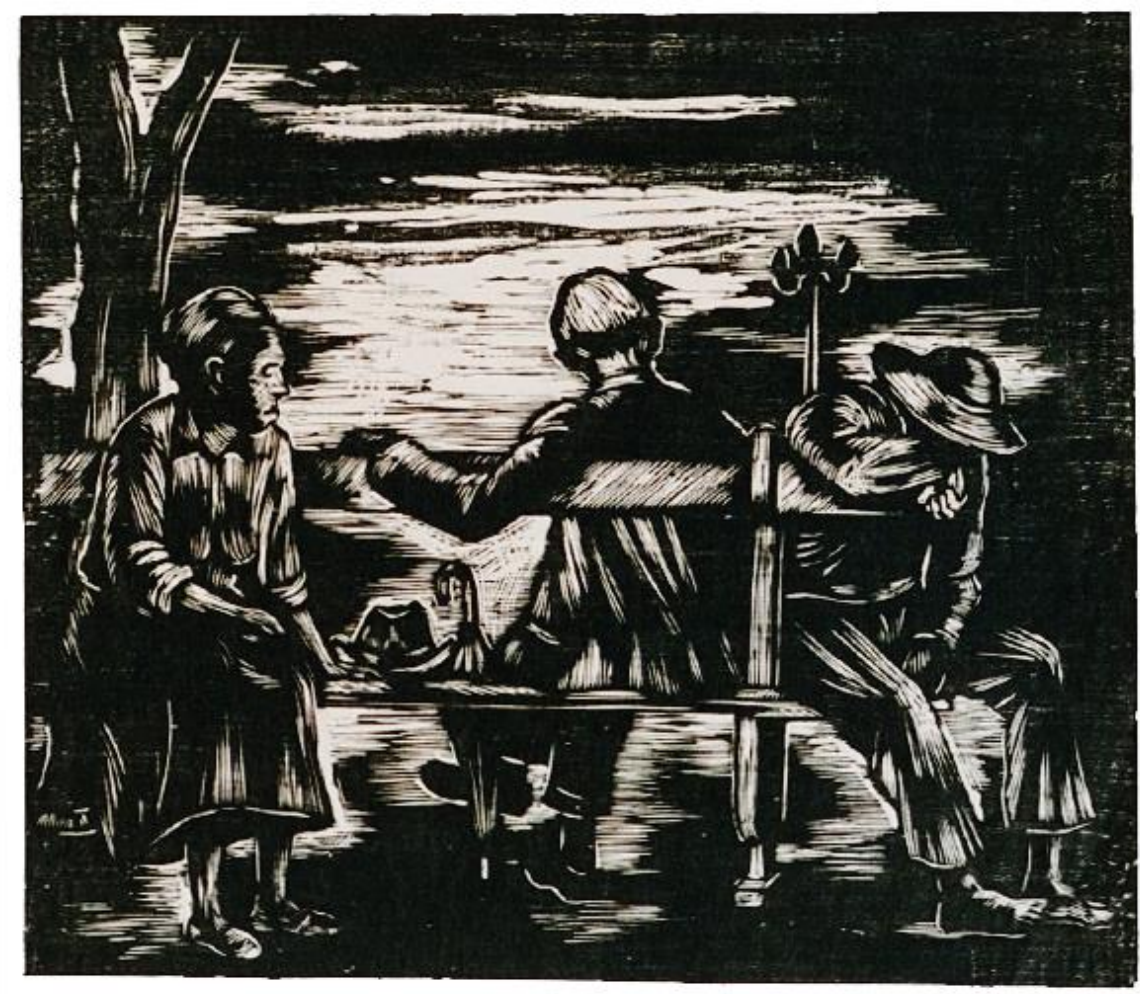

Fonte: CD-ROM Academicismo e Modernismo em Santa Catarina, 2010.

Na xilogravura Descanso, de 1955, Hugo Mund Jr. apresenta três personagens carregados dessas "especificidades e historicidade". Em síntese, na imagem, dois homens e uma mulher encontram-se sentados num banco, além disso, há uma árvore e mais à frente um poste (Figura 1). Mas, como bem disse Didi-Hubermann: “As noções de memória, montagem e dialética estão aí 
para indicar que as imagens não são nem imediatas, nem fáceis de entender" (DIDI-HUBERMANN, 2012, p. 213).

Nem são imediatas, nem fáceis: são incêndios (DIDI-HUBERMANN, 2012). E no contato com a obra de Hugo Mund Jr. algo mais ardia. Algo para além dos gracejos técnicos, das ranhuras solares evidenciadas nos cortes brancos das goivas. Uma praça pública, um pôr-do-sol rajado, e toda sua melancolia, isso estava dado: estávamos diante de um descanso urbano, de citadinos díspares, mergulhados em seu cansaço sorumbático. Relembra-se, no entanto, que "saber olhar uma imagem seria, de certo modo, tornar-se capaz de discernir o lugar onde arde, o lugar onde sua eventual beleza reserva um espaço a um 'sinal secreto', uma crise não apaziguada, um sintoma. O lugar onde a cinza não esfriou" (Ibidem, p. 215). Mas, diante desta obra, como achegar-se deste ardor tremeluzente? Como reconhecer onde as cinzas ainda estão quentes, lançando suas pequenas chamas no tecido do olhar?

Figura 2 - Dos pés no chão. Dos pés galantes. Dos pés descalços.
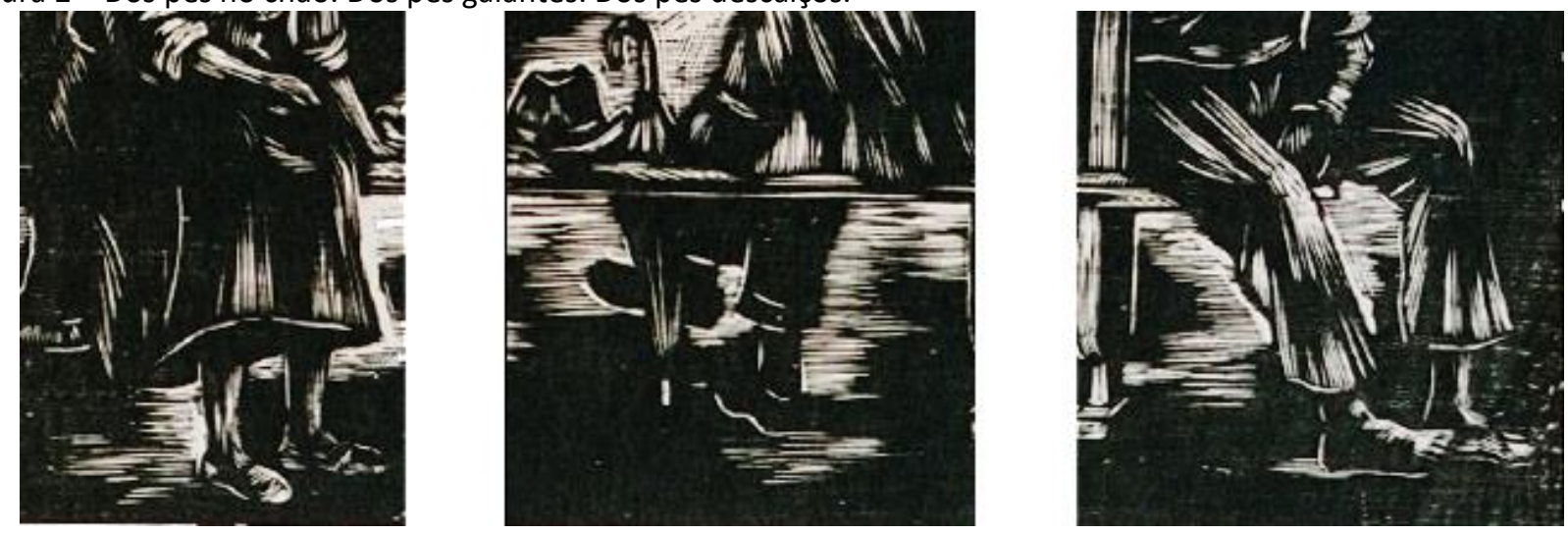

Fonte: Detalhes da obra Descanso, de Hugo Mund Jr. 1955.

Insurgem, então, as "memórias em brasa", a imaginação em pólvora, e todas as suas montagens. Diante da imagem, confrontando este desconsolo de urbe, inflamavam-se, pois, pequenos tremores da curiosidade, do desejo de saber: quem são essas pessoas? Como, mesmo tão ímpares, figuram esta sensação e espaço em comum? Foi na fogueira da rememoração e imaginação que ouvimos uma velha avó dizer: "Se quer saber o que uma pessoa faz, olhe para os seus pés". Lançamos, então, o olhar para esse recorte, esse detalhe (Figura 2), o sintoma e cinza ainda ardente. Lá, na imagem, três pés e sapatos contavam sua própria história; suas próprias memórias e verdades. Ali, onde as ranhuras do sol poente mais parecem a superfície iluminada de 
um rio e desenham formas em suas sombras contraluz, percebemos que não havia apenas um Descanso, mas três. Três pés e seus cansaços.

Figura 3 - Dans La Cuisine, Theophile Steinlen.

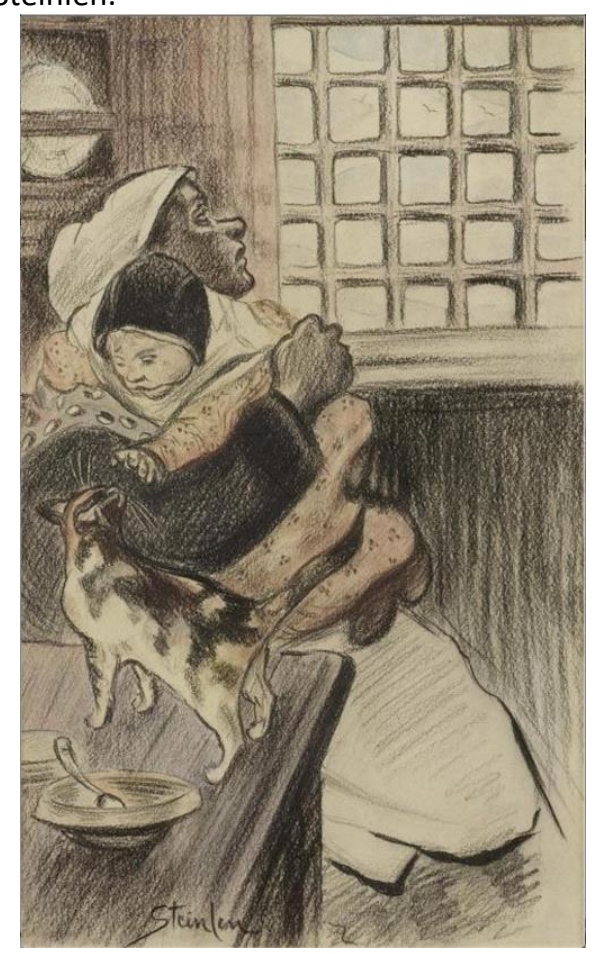

Fonte: http://www.wikiart.org/.

Dos pés no chão. Estes pés fincados no chão, quase enraizados, são pés femininos, com sua sapatilha de pouca sola. E mesmo as sapatilhas, em seu intuito de proteger os pés do contato com o chão, aparecem aqui com essa firmeza do toque com o que é plano, com o que é de solo e sobriedade. Os dois pés estão no chão, retos, firmes, sustentam o peso dessa seriedade feminina; uma retidão de quem precisa estar ligada à superfície, sem saltos e ornamentos. São os pés daquelas que foram escravas, das amas, das empregadas domésticas, das lavadeiras, das feirantes, das cuidadoras. São pés de mulheres que tem as costas curvadas, os seios abatidos, os cabelos obtusos e ocultados; são os sapatos daquelas que carregam consigo o labor diário, o peso fatigado dos dias repetitivos, o olhar desesperançoso. Olhos como aqueles que se vê na ilustração Dans $L a$ Cuisine, de Theophile Steinlen (Figura 3): com seu ar neurastênico, de contornos profundos, que esperam correr as horas para findar mais um dia; e, possivelmente, findá-lo com os mesmos pés 
cansados da obra de Hugo Mund Jr.: fincados no chão, num banco de praça qualquer, cravados na melancolia do tempo.

Dos pés galantes. Estes são pés masculinos, de sapatos garbosos e que não surgem desacompanhados: têm como consortes o chapéu e o guarda-chuva. Lembranças simbólicas de uma posição, de um status quo que o distingue. De pernas cruzadas, um pé toca o chão e o outro não. O cansaço aqui não é, pois, aquele do corpo fatigado, que precisa fincar-se no chão como forma de ligar-se à vida, ao solo. Este é um cansaço alocado entre o que é superfície e o que é elevação: é o cansaço mental, filosófico, das aspirações ulteriores. São pés protegidos, com sapatos lustrados, que entregam-nos os homens de negócios, os proprietários, os pensadores, trajados em linho e com seu cabelo bem asseado. Seu descanso é o daqueles que contemplam, rememoram e refletem sobre a vida. À este homem e seus sapatos galantes é permitido reconhecer a beleza do fenômeno solar, como acontecimento, como monumento simbólico do tempo e, por isso, à ele é permitido contemplar; à ele é possibilitado estar posto diante do tempo e alheio à fadiga do corpo e alienação da mente.

Figura 4 - Farmer, Constant Permeke. 1928.

Fonte: http://www.wikiart.org/.

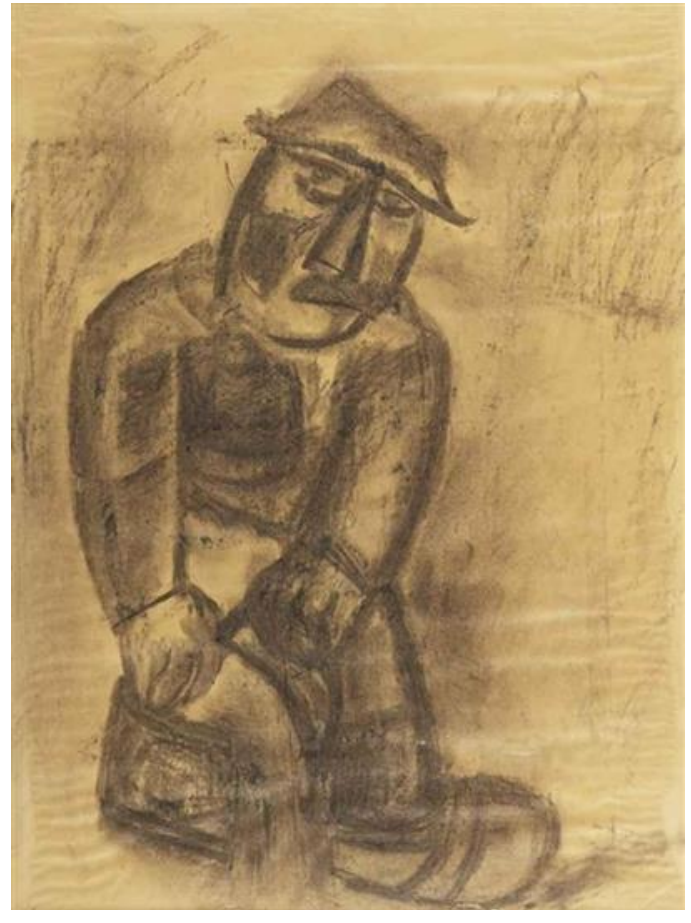


Dos pés descalços. Estes são os pés do homem comum, rude, primitivo. Daqueles que o fazer não permite revestir os pés, pois são os que se lançam ao mar, os que carregam fardos e sacos, os que puxam, erguem, capinam. O pé desnudo pertence a estes homens que precisam sentir o chão e seus dizeres: seu o calor, sua textura e solidez. Constant Permeke, em 1928, representou a aspereza e sobrepeso destes homens, através da figura de um agricultor (Figura 4).

Tanto o homem exausto de Permeke quanto o de pés descalços em Hugo Mund Jr são trabalhadores de força bruta, que carregam pesos de quilos, mas também pesos de tempo e amargura. E, por isso, seu cansaço é essa fadiga de tombo, que desestabiliza as pernas, que desaba a cabeça; é um desmembramento estafado, que - no nosso homem de pés descalços - encontra acalanto apenas no singelo toque de um pé no outro. Ali onde um dedão acosta-se noutro calcanhar, está o roçar da pele rachada e cinzenta, um contato como lembrança de que este homem existe em carne-viva; que é humano, mesmo com tudo.

São três pés, com seus calçados e cansaços, unos em suas disparidades e inscritos num mesmo território, numa mesma memória social. Há ainda, porém, um outro elemento sintomático que lança suas faíscas acesas nesse processo de rememoração engramática: o banco. Um partícipe que oferece descanso tanto para os pés mais nobres, garbosos e galantes, quanto para aqueles apegados ao firmamento, de sobriedade e rudeza, sejam calçados ou desnudos. O banco como símbolo daquilo que lhe envolve: a cidade, o espaço urbano. Desvela-se, então, que é o ambiente da cidade que permite esta vivência e montagem visual de tempos, personagens e memórias distintas; que abarca e abraça os diferentes fazeres e seus cansaços. E é no banco de praça, em todo seu potencial simbólico, que se demarca a percepção de um cansaço comum, uma fadiga rotineira ao citadino. Assim, o banco ganha uma sobrevida, como costume, como um gesto, uma permanência da fórmula do urbano: multíplice em sua culturalidade e estafante em sua temporalidade.

A obra de Hugo Mund Jr. enlaça seu caráter de representar, de fazer existir, de dar visibilidade a essas imagens e sujeitos ocultos nos contornos da cidade de Florianópolis, na década de 50. Na imagem vemos reverberar o intuito compartilhado pelos artistas da época, de representar "um mundo de trabalho, de sofrimento, de desconcertos, de improvisos e até mesmo de banalidades, mas que fazem parte da vida do cidadão" (LEHMKUHL, 1996, p. 49). Olhamos para três pés em seus cansaços, mas o que vimos costurar-se foram três símbolos de um imaginário 
social, representantes de problemáticas atemporais; engramas culturais e políticos talhados numa imagem incendiária.

Naquele banco de praça, ao pôr-do-sol rajado da cidade de Florianópolis, os três pés apartados se unificam, são herdeiros de um caráter em comum: a vida na modernidade. Talvez não o soubessem - também eu não o sabia - que tamanha metafísica havia nos seus pés e calçados. Somos como legatários do caipora suicida Matias Deodato de Castro e Melo, de Machado de Assis, que deixa como testamento mais do que pares de botas para os desvalidos: deixa a nós, passageiros desatentos da cidade, uma lembrança das imagens que se entrepõem nos instantes fugidios; oferece-nos a percepção das histórias que se ocultam nos detalhes, daquilo que as sutilezas podem narrar:

No fim de dez minutos, vi passar um homem bem trajado, fitando a miúdo os pés. Conhecia-o de vista; era uma vítima de grandes reveses, mas ia risonho, e contemplava os pés, digo mal, os sapatos. Estes eram novos, de verniz, muito bem talhados, e provavelmente cosidos a primor. Ele levantava os olhos para as janelas, para as pessoas, mas tornava-os aos sapatos, como por uma lei de atração, interior e superior à vontade. la alegre; via-se-lhe no rosto a expressão da bem-aventurança. Evidentemente era feliz; e, talvez, não tivesse almoçado; talvez mesmo não levasse um vintém no bolso. Mas ia feliz, e contemplava as botas. A felicidade será um par de botas? Esse homem, tão esbofeteado pela vida, achou finalmente um riso da fortuna. Nada vale nada. Nenhuma preocupação deste século, nenhum problema social ou moral, nem as alegrias da geração que começa, nem as tristezas da que termina, miséria ou guerra de classes; crises da arte e da política, nada vale, para ele, um par de botas. Ele fita-as, ele respira-as, ele reluz com elas, ele calça com elas o chão de um globo que lhe pertence. Daí o orgulho das atitudes, a rigidez dos passos, e um certo ar de tranqüilidade olímpica... Sim, a felicidade é um par de botas. (ASSIS, 1884, p. 47, grifo nosso).

É assim, pois, no detalhe, que sobrevive a ardência da imagem. Os pés cansados de Hugo Mund Jr. não cessam de arder, e não cessarão. A possibilidade de montagem constelar entre memórias, imagens, tempos, não interrompe seus movimentos e tensões. Por isso, nas goivas desta xilogravura e até mesmo nestes pés destrinchados em suas fadigas, há ainda cinzas ardentes, faíscas expostas, à espera daqueles que tem coragem de aproximar-se do incêndio das imagens. Ademais, com os meus próprios pés já cansados, só posso aconselhá-los usando as mesmas palavras finais do caipora Matias Deodato: "Boa noite, e calçai-vos!". 


\section{REFERÊNCIAS}

AGAMBEN, Giorgio. Aby Warburg e a ciência sem nome. In: BARTHOLOMEU, Cezar (Org.). Dossiê Warburg. Revista Arte \& Ensaios. Ano XVII, n. 19, 2009. p. 132-143. Disponível em: $<$ https://www.ppgav.eba.ufrj.br/wp-content/uploads/2012/01/ae22_dossie_CezarBartholomeu_Aby-Warburg_Giorgio-Agamben1.pdf>. Acesso em: 12 jul. 2018.

ASSIS, Machado de. Último capítulo In: Histórias sem data. Rio de Janeiro: Guarnier, 1884.

CANTINHO, Maria João. Aby Warburg e Walter Benjamin: a legibilidade da memória. História Revista, Goiânia, v. 21, n. 2, p.24-38, mai./ago. 2016. Disponível em: <https://www.revistas.ufg.br/historia/article/view/43380/21805>. Acesso em: 13 jul. 2018.

CERTEAU, M. de. A escrita da história. Rio de Janeiro: Forense Universitária, 1982.

DIDI-HUBERMAN, Georges. Quando as imagens tocam o real. Pós: Revista do Programa de Pós Graduação em Artes da Escola de Belas Artes da UFMG, Belo Horizonte, v. 2, n. 4, p.204-219, nov. 2012. Disponível em: <https://www.eba.ufmg.br/revistapos/index.php/pos/article/view/60/62>. Acesso em: 13 jul. 2018.

KERN, Maria Lúcia Bastos. Historiografia da arte face às mudanças de paradigmas: memória e tempo. In: COLÓQUIO DO COMITÊ BRASILEIRO DE HISTÓRIA DA ARTE, 29., 2009, Vitória. Anais... . Rio de Janeiro: Comitê Brasileiro de História da Arte, 2009. p. 87 - 97. Disponível em: <http://www.cbha.art.br/coloquios/2009/anais/pdfs/anais_coloquio_2009.pdf>. Acesso em: 13 jul. 2018.

LEHMKUHL, Luciene. Imagens além do círculo: o grupo de artistas plásticos de Florianópolis e a positivação de uma cultura nos anos 50. 1996. 126 f. Dissertação (Mestrado) - Curso de Mestrado em História, Curso de Pós Graduação em História, Universidade Federal de Santa Catarina, Florianópolis, 1996. Disponível em: <https://repositorio.ufsc.br/handle/123456789/111312>. Acesso em: 13 jul. 2018.

MAKOWIECKY, Sandra. Teoria e História da arte: pressupostos metodológicos no PPGAV-UDESC. Revista Ciclos, Florianópolis, v. 1, n. 1, p.01-21, set. 2013. Disponível em: <http://www.revistas.udesc.br/index.php/ciclos/article/view/3860>. Acesso em: 13 jul. 2018.

MERLEAU-PONTY, Maurice. O visível e o invisível. 4. ed. São Paulo: Editora Perspectiva, 2003.

PROUST, Marcel. No caminho de Swann. 3. ed. São Paulo: Globo, 2006.

SAMAIN, Etienne. Antropologia, imagens e arte: um percurso reflexivo a partir de Georges DidiHuberman. Cadernos de Arte e Antropologia, [s. I.], v. 3, n. 2, p.47-55, jan. 2014. Disponível em: <https://journals.openedition.org/cadernosaa/391?file=1>. Acesso em: 12 jul. 2018. 
Pés e cansaços: imagens e memórias na obra Descanso, de Hugo Mund Jr.

Clarissa Santos Silva

WARBURG, Aby. Histórias de fantasma para gente grande. São Paulo: Companhia das Letras, 2015. 